\begin{tabular}{l|l} 
& $\begin{array}{l}\text { Eastern } \\
\text { European } \\
\text { Countryside }\end{array}$ \\
\hline DOI: $10.2478 /$ eec-2014-0007 & $20^{\prime} 2014$
\end{tabular}

\author{
Ivana Blešić, Tatjana Pivac, Snežana Besermenji, \\ Andjelija Ivkov-Džigurski, Kristina Košić
}

\title{
Residents' Attitudes and Perception towards Tourism Development: A Case Study of Rural Tourism in Dragacevo, Serbia
}

\begin{abstract}
This research examined the residents' profile, attitudes, and perception towards tourism development based on 176 respondents interviewed. Residents' attitudes toward tourism were measured by adapting 24 items from the Tourism Impact Attitude Scale developed by Lankford and Howard (1994). This study aimed at identifying the relationships between residents' socio-economic and demographic attributes and their attitudes toward tourism by focusing on villages where tourism is in the development stage.

Key words: rural tourism, development, residents' attitudes, TIAS scale, Dragacevo, Serbia

\section{Introduction}

The rural areas of Central and Eastern Europe face severe challenges related to the lack of non-farm employment. In the last two decades, agricultural employment stagnated, and many rural commuters lost their income due to the closure of industrial enterprises in urban centers. New non-agricultural jobs, which could absorb the released labor, have hardly emerged in rural
\end{abstract}


areas outside of the booming metropolitan areas. At the same time, the diversification of rural areas is hindered by the lack of agglomeration advantages, particularly in peripheral regions. One potential source of income, often cited as an opportunity for rural areas, is rural tourism (Baum 2012).

Serbia has favorable conditions for the development of rural tourism. The national strategy of the Republic of Serbia assigns priority to this type of tourism among those which are of special interest (The National Strategy of Tourism of the Republic of Serbia 2005). Although rural tourism could bring several billions of Euros of profit a year, Serbia does not have material conditions for accommodating larger numbers of tourists. According to the data published in the study conducted by the Faculty of Economy from Subotica, 300 Serbian households are permanently involved in rural tourism, together with 800 households which are temporarily part of this industry. The households' owners live and work in the following regions: Kosjeric, Ljig, Cacak, Pozega, Brus, Uzice and Sokobanja. In 43 municipalities, there are 2568 registered beds which enable 100000 stays a year (http://www. b92.net/putovanja/zanimljivosti.php?.yyyy $=2012 \& \mathrm{~mm}=03 \& \mathrm{dd}=05 \& \mathrm{nav}_{-}$ $\mathrm{id}=587962,2013-05-19)$.

One of the regions, where rural tourism is being developed, is Dragacevo. Dragacevo is the area in the Western Serbia which occupies the territory of $661 \mathrm{~km}^{2}$. This area consists of municipality Lucani together with part of the following municipalities: Cacak, Kraljevo, Ivanjica, Arilje and Pozega. Dragacevo comprises 47 rural and 2 urban settlements (Lucani and Guca). Due to its favourable geographical position, Dragacevo has obvious potential for tourism development. Many people consider it to be the most picturesque area in Serbia, known as "Little Switzerland". It is situated among four mountains: Ovcar, Jelica, Troglav and Golubac (http:// www.vajati.com/srp/?p=116, 2013-05-19).

The most famous tourist feature of Dragacevo is the Trumpet festival which dates back to 1961. Other sights and attractions include old monasteries and churches, monuments by the road, organic food production, long tradition and warm hospitality (http://www.paunpress. com/user/tur.php?id=921, 2013-05-19). Rural tourism in Dragacevo started to expand in the $80 \mathrm{~s}$. Since then, the number of households involved in tourism has been growing continuously. The biggest number of them is in the villages of Kaona (on the road from Guca to Kraljevo), Gornja 
Kravarica and Lisa (http://www.stil-magazin.com/clanak/broj-69-24-april2008/dragacevo, 2013-05-19).

The main goal of this research was to analyze and present the attitudes of the local population towards tourism development in rural areas of Dragacevo region. The findings of the study can be useful to the tourist industry organizers for increasing the social benefits generated by the rural tourism development and reducing its negative social impacts.

\section{Literature Review}

Comprehending local residents' attitudes toward tourism development is crucial for the success and sustainability of any type of tourism development. There is a large number of studies which have examined resident attitudes and the factors that are likely to influence those attitudes. The findings of most of those studies show that locals tend to have positive attitudes because they see tourism as an economic development tool (Gursoy, Chi, Dyer 2009; Gursoy, Jurowski, Uysal 2002). In order to provide continuous functioning of tourism and mutually beneficial relationship between tourists and local resident, hosts must be "willing partners" (Long, Perdue, Allen 1990).

Studies on resident attitudes toward tourism impacts date back to the 70 s, and they suggest an increase in range and number during the course of the years (Kuvan, Akan 2009). As the literature shows, among the intrinsic factors, economic dependency on tourism is a significant variable underlying residents' positive perceptions of the impacts and favorable attitudes toward tourism development in a vast majority of the studies (Kuvan, Akan 2009; Pizam 1978; Thompson, Crompton, Kamp 1979; Snaith, Haley 1999). Some study results also suggest that other demographic characteristics can influence attitude of residents toward tourism. According to these results, residents supportive of tourism development are generally young (Haralambopoulas, Pizam 1996; Husbands 1989) and educated (Korca 1998; Husbands 1989). The results of certain studies show that the longer respondents lived in the community, the more negative they were toward tourists and tourism (Lankford, Howard 1994; Brougham, Butler 1981; Liu, Var 1986; Urn, Crompton 1987).

While some researchers reported significant differences between respondent characteristics and their attitudes toward tourism in an area, others reported that socio-economic variables were not good predictors 
of residents' attitudes toward tourism. The above mentioned studies were conducted by applying different models of surveying local residents' attitudes towards tourism development in their area. Lankford and Howard (1994) developed the tourism impact attitude scale (TIAS), which enables researchers to measure residents' attitudes toward tourism in different contexts. The questionnaire consists of 27 items grouped around two factors. In the last two decades, this questionnaire was used in various tourism destinations. The results of application of TIAS model proved its reliability and validity for measuring local peoples' attitudes. Most of the researchers apply TIAS model when measuring the attitudes of local residents in developed tourist destinations (such as Hawaii, Charleston South Carolina, New Orleans, Louisiana) (Wang, Pfister, Morais 2006).

\section{Methodology}

\section{Research instrument}

To examine residents' attitudes toward tourism in Dragacevo, Serbia, the researchers adopted 24 statements from TIAS. Three items (I support charging tax or fee for tourism development, Tourism lowers possibility of the outdoor recreation in my area and Tourism caused the increase of crime rate in my area) were deleted from the survey instrument due to its low loading factor score (less than 0.5). Five-point Likert type scale was used for measuring the attitudes of local residents (where $1=$ strongly disagree, 2 = disagree, 3 = neutral, $4=$ agree, $5=$ strongly agree $)$.

\subsection{Survey}

The survey was conducted during July and August in 2012 in Dragacevo area, in two urban (Guca and Lucani) and 12 rural settlements: Gornja and Donja Kravarica, Lisa, Kaona, Zeoke, Kotraza, Markovica, Rtari, Tijanje, Turica, Pilatovic and Puhovo. Fifteen research assistants, the authors of the paper and ten senior students carried out the research. In total, 300 questionnaires were distributed and $176(58.7 \%)$ usable questionnaires were obtained. 


\section{Results}

\section{Characteristics of respondents}

The sample included $56.8 \%$ males and $43.2 \%$ females among the respondents. The main age group was between 31 and 40 years and represented 20.5\% of the total group of respondents. The next biggest group was the group between 51 and 60 years of age, thus making 18.2\% of the whole sample. Most of the respondents (64.2\%) completed secondary education.

Most of the surveyed people were born in the same place where the research took place (77.3\%), and $22.7 \%$ have been living there for more than 10 years. More than half of them (51.7\%) work part-time or full-time in tourism industry. Although majority of the local residents rarely travel (72.2\%), $67.6 \%$ of them have frequent contact with tourists.

Table 1. Socio - demographic information of visitors $(n=176)$

\begin{tabular}{|l|r|r|}
\hline \multicolumn{1}{|c|}{ Variables } & \multicolumn{1}{|c|}{$\begin{array}{c}\text { Sample } \\
\text { size }\end{array}$} & Percentage \\
\hline Age & & \\
\hline$\leq 20$ & 12 & 6.8 \\
\hline $21-30$ & 20 & 11.4 \\
\hline $31-40$ & 36 & 20.5 \\
\hline $41-50$ & 24 & 13.6 \\
\hline $51-60$ & 29 & 18.2 \\
\hline $61-70$ & 23 & 16.5 \\
\hline$\geq 71$ & & 13.1 \\
\hline Gender & 100 & 56.8 \\
\hline Male & 76 & 43.2 \\
\hline Female & & \\
\hline Education & 23 & 13.1 \\
\hline Elementary & 113 & 64.2 \\
\hline Secondary & 40 & 22.7 \\
\hline Higher & & \\
\hline
\end{tabular}


Table 1. Socio - demographic information

\begin{tabular}{|l|r|r|}
\hline \multicolumn{1}{|c|}{ Variables } & \multicolumn{1}{|c|}{$\begin{array}{c}\text { Sample } \\
\text { size }\end{array}$} & Percentage \\
\hline Place of birth & & \\
\hline In the place of research & 136 & 77.3 \\
\hline Other & 40 & 22.7 \\
\hline Length of stay in the place of research & & \\
\hline From birth & 136 & 77.3 \\
\hline$\leq 10$ years & 6 & 3.4 \\
\hline$\leq 20$ years & 8 & 4.5 \\
\hline$\geq 21$ years & 26 & 14.8 \\
\hline Job connected to tourism & 54 & 30.7 \\
\hline Yes & 85 & 48.3 \\
\hline No & 37 & 21.0 \\
\hline Partly & & \\
\hline Frequency of travelling & 119 & 1.1 \\
\hline Frequently & 55 & 26.7 \\
\hline Rarely & 2 & 72.2 \\
\hline Never & & 1.1 \\
\hline Communication with tourists & & \\
\hline Frequently & & 31.3 \\
\hline Rarely & & \\
\hline Never & & \\
\hline
\end{tabular}

Source: own research.

\section{Factor analysis}

The attribute data were factors analyzed using the principal component method and varimax rotation procedure in order to extract the subdimensions of those attributes. Factors with eigenvalue greater than 1 and with factor loadings more than 0.5 were retained. The results of the factor analysis, which suggested a three-factor solution, included 24 attributes and explained $64.59 \%$ of the variance. The Kaiser - Meyer - Olkin 


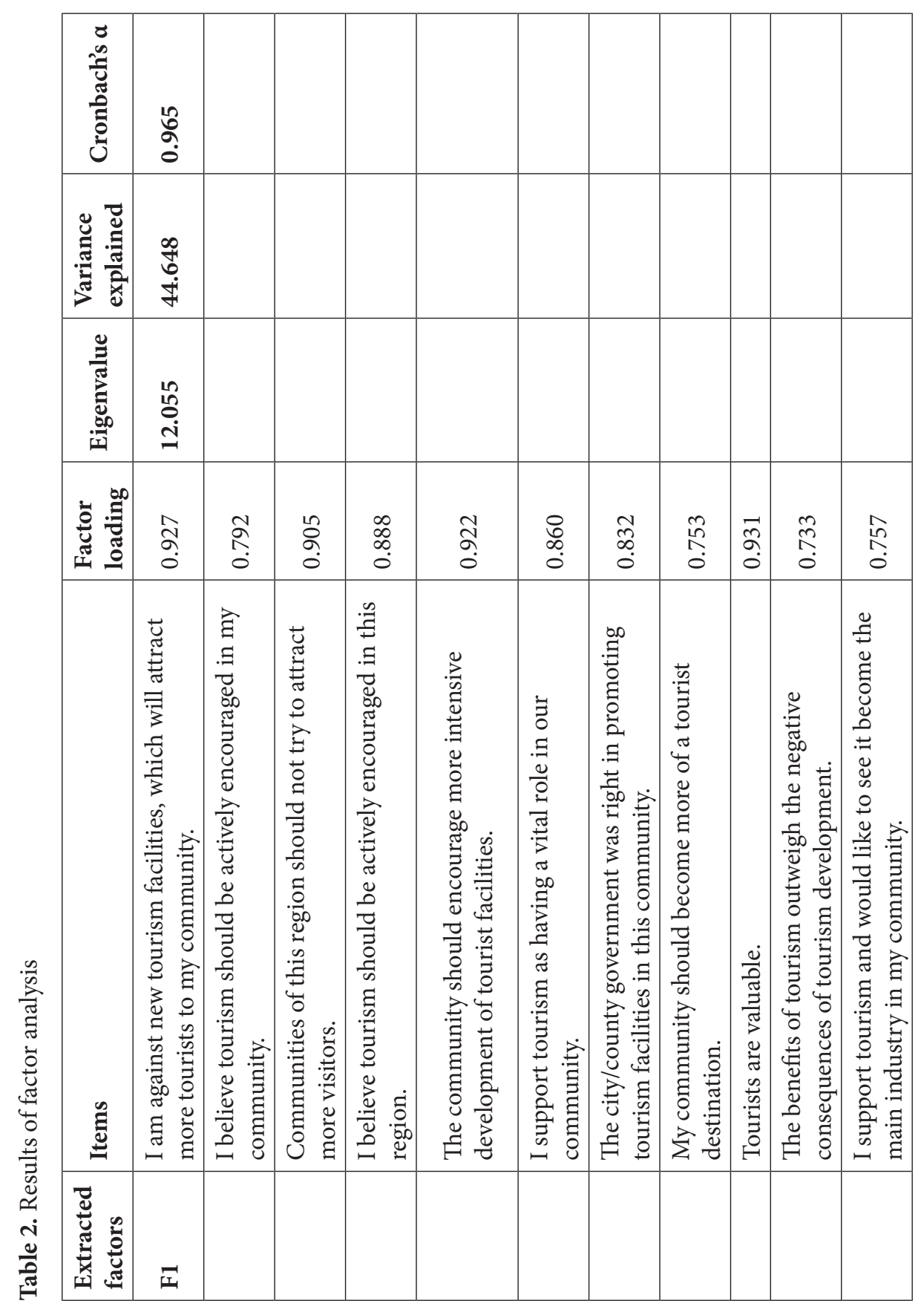




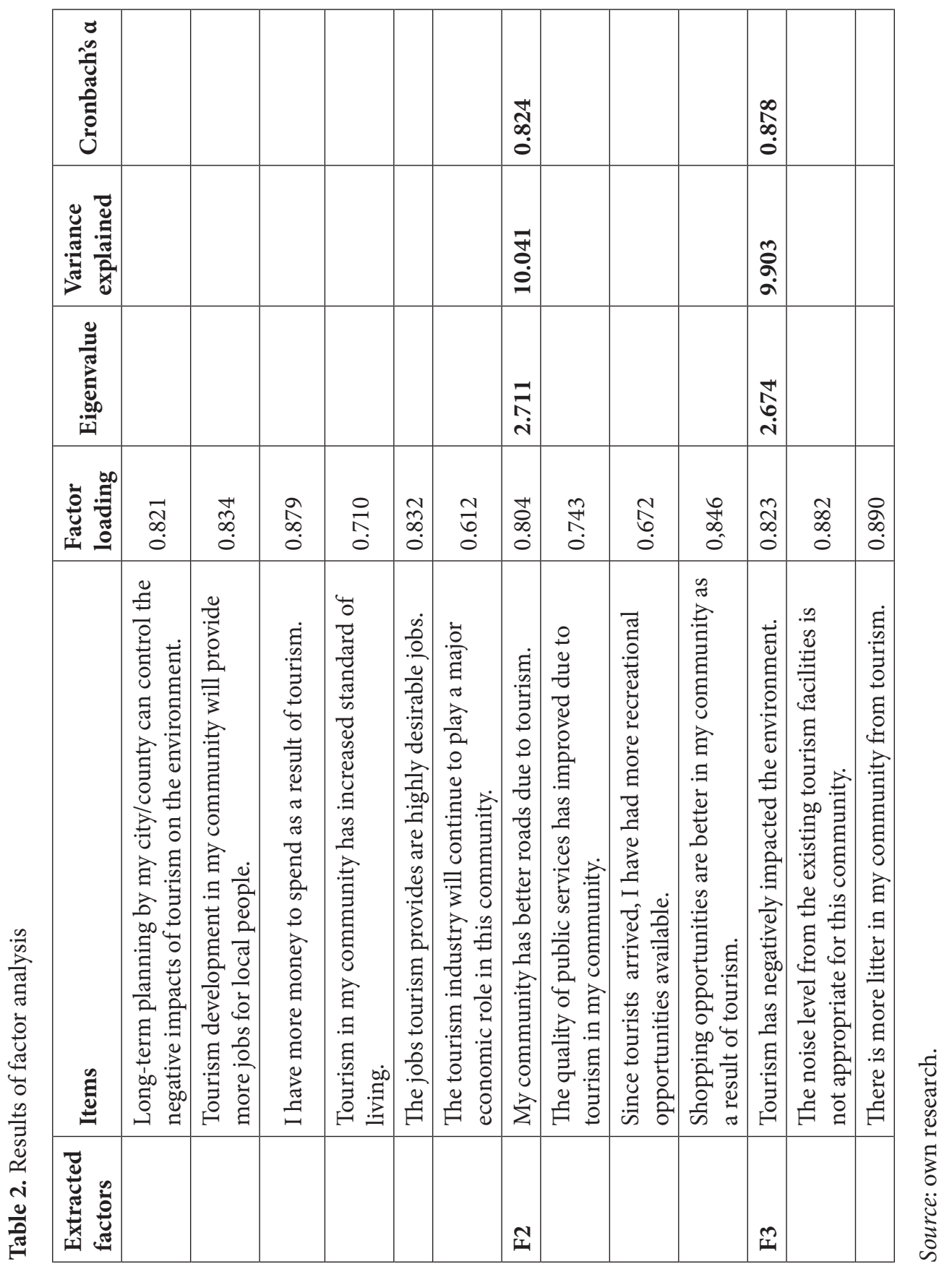


(KMO) overall measure of sampling adequacy was 0.937 which exceeds recommended value of 0.6 (Kaiser 1974) and Bartlett's test of sphericity was significant $(p=0.000)$. The results showed that the Alpha coefficients of the three factors ranged from 0.824 to 0.965 . This demonstrates that the scales of the formal questionnaire have high reliability (Nunnally 1978). Table 2 shows the results of the factor analysis.

The first factor was labeled "Locals' attitude toward tourism". This factor explained $44.648 \%$ of the total variance with a reliability coefficient of 0.965 and it included 17 items. The second factor with four items was "Tourism's positive impacts" explaining $10.041 \%$ of the total variance with a reliability coefficient of 0.824 . The third factor, which had all three items, was labeled "Tourism's negative impacts" and explained $9.903 \%$ of the variance with a reliability coefficient of 0.878 .

\section{Findings}

Based on the results presented in Table 3, it can be concluded that the respondents assigned the biggest marks to the first and the second factors, which means that local population has positive attitude towards tourism and that they are aware of the benefits that the local communities have from tourism development.

In the first factor set of questions, the biggest marks were given to the following: "I support tourism and would like to see it become the main industry in my community" and "Tourists are valuable".

The lowest mark was given to the question "I have more money to spend as a result of tourism" which points out that tourism is still developing in these areas and that local residents are aware of tourism being economically important industry in future.

Analysis of variance ANOVA was used in order to examine the attitude of local population based on their socio-demographical characteristics. The results showed that the respondents belonging to age category up to 50 have a statistically more important positive attitude toward tourism than older respondents (Table 4).

In the other two factors, there are no statistical importance compared to the age of respondents.

The results of variance ANOVA based on education (Table 5) suggested that the respondents with higher level of education (high school and 
university diplomas) have more positive attitude toward tourism and that they are more aware of its importance. Also, local inhabitants, who more frequently communicate with tourists and whose work is connected to tourism, gave higher marks to statements which support tourism development and which point out its importance for socio-economical prosperity of the community (Tables 6 and 7).

Table 3. Mean ratings of factors and items

\begin{tabular}{|l|c|c|}
\hline $\begin{array}{l}\text { Selected } \\
\text { factors and items }\end{array}$ & Mean & $\begin{array}{c}\text { Std. } \\
\text { Dev. }\end{array}$ \\
\hline F1 - “Locals' attitude toward tourism“ & $\mathbf{3 . 8 5 9 3}$ & $\mathbf{0 . 9 6 7 8 4}$ \\
\hline $\begin{array}{l}\text { I am against new tourism facilities, which will attract more } \\
\text { tourists to my community. }\end{array}$ & 3.6080 & 1.49274 \\
\hline $\begin{array}{l}\text { I believe tourism should be actively encouraged in my } \\
\text { community. }\end{array}$ & 3.5000 & 1.42628 \\
\hline $\begin{array}{l}\text { Communities of this region should not try to attract more } \\
\text { visitors. }\end{array}$ & 3.6761 & 1.48235 \\
\hline $\begin{array}{l}\text { I believe tourism should be actively encouraged in this } \\
\text { region. }\end{array}$ & 3.6932 & 1.50700 \\
\hline $\begin{array}{l}\text { The community should encourage more intensive } \\
\text { development of tourist facilities. }\end{array}$ & 3.6705 & 1.51730 \\
\hline $\begin{array}{l}\text { The tourism industry will continue to play a major } \\
\text { economic role in this community. }\end{array}$ & 4.0966 & 0.96616 \\
\hline $\begin{array}{l}\text { The city/county government was right in promoting } \\
\text { tourism facilities in this community. }\end{array}$ & 3.9943 & 1.21654 \\
\hline $\begin{array}{l}\text { My community should become more of a tourist } \\
\text { destination. }\end{array}$ & 4.1364 & 0.95835 \\
\hline Tourists are valuable. & 4.2614 & 0.97388 \\
\hline $\begin{array}{l}\text { The benefits of tourism outweigh the negative } \\
\text { consequences of tourism development. }\end{array}$ & 0.92245 \\
\hline $\begin{array}{l}\text { I support tourism and would like to see it become the } \\
\text { main industry in my community. }\end{array}$ & 0.84790 \\
\hline $\begin{array}{l}\text { Long-term planning by my city/county can control the } \\
\text { negative impacts of tourism on the environment. }\end{array}$ & 0.92032 \\
\hline $\begin{array}{l}\text { Tourism development in my community will provide more } \\
\text { jobs for local people. }\end{array}$ & 3.6818 & 1.27880 \\
\hline
\end{tabular}


Table 3. Mean ratings of factors and items

\begin{tabular}{|l|c|c|}
\hline $\begin{array}{l}\text { Selected } \\
\text { factors and items }\end{array}$ & Mean & $\begin{array}{c}\text { Std. } \\
\text { Dev. }\end{array}$ \\
\hline I have more money to spend as a result of tourism. & 3.3011 & 1.43634 \\
\hline $\begin{array}{l}\text { Tourism in my community has increased standard of } \\
\text { living. }\end{array}$ & 3.7330 & 0.73465 \\
\hline The jobs tourism provides are highly desirable jobs. & 3.7045 & 0.78061 \\
\hline $\begin{array}{l}\text { The tourism industry will continue to play a major } \\
\text { economic role in this community. }\end{array}$ & 3.7045 & 0.78061 \\
\hline F2 - "Tourism's positive impacts & $\mathbf{3 . 8 4 8 0}$ & $\mathbf{0 . 7 9 7 7 5}$ \\
\hline My community has better roads due to tourism. & 3.7045 & 1.07607 \\
\hline $\begin{array}{l}\text { The quality of public services has improved due to tourism } \\
\text { in my community. }\end{array}$ & 3.9432 & 0.88619 \\
\hline $\begin{array}{l}\text { Since tourists arrived, I have had more recreational } \\
\text { opportunities available. }\end{array}$ & 3.8807 & 1.09151 \\
\hline $\begin{array}{l}\text { Shopping opportunities are better in my community as a } \\
\text { result of tourism. }\end{array}$ & 3.8636 & 0.87089 \\
\hline F3 - Tourism's negative impacts & $\mathbf{3 . 1 7 6 1}$ & $\mathbf{0 . 6 0 5 7 2}$ \\
\hline Tourism has negatively impacted the environment. & 3.2784 & 0.74588 \\
\hline $\begin{array}{l}\text { The noise level from the existing tourism facilities is not } \\
\text { appropriate for this community. }\end{array}$ & 3.1023 & 0.64214 \\
\hline There is more litter in my community from tourism. & 3.1477 & 0.63317 \\
\hline
\end{tabular}

Source: own research.

Table 4. The results of ANOVA compared to the age of the respondents

\begin{tabular}{|c|c|c|c|c|c|c|c|c|c|}
\hline \multirow[b]{2}{*}{ Factor } & \multicolumn{7}{|l|}{ Means } & \multirow[b]{2}{*}{ F-value } & \multirow[b]{2}{*}{$\begin{array}{l}\text { Scheffe } \\
\text { test }\end{array}$} \\
\hline & $\begin{array}{c}\text { age } \\
\text { group } \\
1 \\
\leq 20\end{array}$ & $\begin{array}{c}\text { age } \\
\text { group } \\
2 \\
21-30\end{array}$ & $\begin{array}{c}\text { age } \\
\text { group } \\
3 \\
31-40\end{array}$ & $\begin{array}{c}\text { age } \\
\text { group } \\
4 \\
41-50\end{array}$ & $\begin{array}{c}\text { age } \\
\text { group } \\
5 \\
51-60\end{array}$ & $\begin{array}{c}\text { age } \\
\text { group } \\
6 \\
61-70\end{array}$ & $\begin{array}{c}\text { age } \\
\text { group } \\
7 \geq 71\end{array}$ & & \\
\hline$F 1$ & 4.6275 & 4.5824 & 4.4216 & 4.1029 & 3.2482 & 3.2698 & 3.2890 & $16.199^{*}$ & $\begin{array}{l}1,2,3,4> \\
5,6,7\end{array}$ \\
\hline
\end{tabular}


Table 5. The results of ANOVA compared to the education of the respondents

\begin{tabular}{|l|l|l|l|l|l|}
\hline \multirow{2}{*}{ Factor } & \multicolumn{2}{|l|}{ Means } & \multirow{2}{*}{ F-value } & Scheffe test \\
\cline { 2 - 4 } & $\begin{array}{l}\text { Group 1 } \\
\text { Elementary }\end{array}$ & $\begin{array}{l}\text { Group 2 } \\
\text { Secondary }\end{array}$ & $\begin{array}{l}\text { Group 3 } \\
\text { Higher }\end{array}$ & & \\
\hline F1 & 3.2890 & 3.8506 & 4.2118 & $7.115^{\star}$ & $1<2,3$ \\
\hline F2 & 3.3804 & 3.9004 & 3.9688 & $4.858^{* *}$ & $1<2,3$ \\
\hline F3 & 2.9275 & 3.1858 & 3.2917 & 2.732 & - \\
\hline
\end{tabular}

Source: own research.

Table 6. The results of ANOVA compared to communication of local resident with tourists

\begin{tabular}{|c|c|c|c|c|c|}
\hline \multirow[b]{2}{*}{ Factor } & \multicolumn{3}{|l|}{ Means } & \multirow[b]{2}{*}{ F-value } & \multirow[b]{2}{*}{ Scheffe test } \\
\hline & $\begin{array}{l}\text { Group } 1 \\
\text { Frequently }\end{array}$ & $\begin{array}{l}\text { Group } 2 \\
\text { Rarely }\end{array}$ & $\begin{array}{l}\text { Group } 3 \\
\text { Never }\end{array}$ & & \\
\hline$F 1$ & 4.4760 & 2.5679 & 2.6765 & $500.843^{*}$ & $1>2,3$ \\
\hline F2 & 4.0252 & 3.4727 & 3.6250 & $10.040^{\star}$ & $1>2$ \\
\hline F3 & 3.2857 & 2.9333 & 3.3333 & $6.865^{\star}$ & $1>2$ \\
\hline
\end{tabular}

Source: own research.

Table 7. The results of ANOVA compared to residents' work

\begin{tabular}{|c|c|c|c|c|c|}
\hline \multirow[b]{2}{*}{ Factor } & \multicolumn{3}{|l|}{ Means } & \multirow[b]{2}{*}{ F-value } & \multirow[b]{2}{*}{ Scheffe test } \\
\hline & $\begin{array}{l}\text { Group } 1 \\
\text { Yes }\end{array}$ & $\begin{array}{l}\text { Group } 2 \\
\text { Partly }\end{array}$ & $\begin{array}{l}\text { Group } 3 \\
\text { No }\end{array}$ & & \\
\hline$F 1$ & 4.5675 & 4.1431 & 3.2858 & $47.392^{\star}$ & $1>2,3$ \\
\hline$F 2$ & 4.0139 & 3.7770 & 3.7735 & 1.698 & - \\
\hline F3 & 3.3704 & 3.2883 & 3.0039 & $7.342^{*}$ & $1,2>3$ \\
\hline
\end{tabular}

Source: own research.

\section{Conclusions}

This study reinforced previous research findings and supported the premise that TIAS is a reliable and valid instrument to measure residents' attitudes 
toward tourism. Additionally, the study findings provided a glimpse of residents' attitudes toward tourism in the study area. It indicated that most respondents are favorable toward tourism. The results of this study illustrated that residents are aware of the benefits, as well as the problems caused by tourism in rural areas. Furthermore, ranking of the mean responses for each dimension in the study showed that respondents expressed the highest level of agreement with the statements that tourism activity in the area has brought with it economic benefits.

The analysis of the responses indicated that residents' evaluation of the economic and socio-cultural impacts are significantly diverse depending on their socio-demographic characteristics. The results showed that residents working in tourism industry have significantly more positive attitude towards tourism development compared to the residents not involved in the industry. At the same time, residents who benefit economically from tourism are more aware of its negative influence on the environment.

It is important to point out that the results of this research confirmed that the older respondents and those living there all their lives were more negative towards tourists and tourism, which is typical for the research of the attitudes of local residents in other regions

(Haralambopoulas, Pizam 1996; Husbands 1989; Lankford, Howard 1994; Brougham, Butler 1981; Liu, Var 1986; Urn, Crompton 1987).

Respondents with lower level of education and those who do not communicate with tourists have negative perception of tourism development and its importance to the prosperity of local community. Korca (1998) and Husbands (1989) had the same findings in their researches.

The findings supported the idea that educating residents about the potential benefits of tourism is critical in obtaining the support for tourism development, and in achieving sustainable community development. Taking into consideration natural and anthropogenic potentials of Dragacevo area, high expectations of further tourism development that the local residents show should not be surprising. However, future sustainability in tourism development will inevitably require more involvement of local residents in the planning and management of rural tourism in Serbia.

The result of this study cannot be universalized because of the unique characteristics of the area. For a better insight of the residents' attitudes toward tourism, further studies in other geographical areas, but in different settings, are needed. Residents' attitudes and perception towards tourism 
development may also show variances according to the different types of tourism activity (mass tourism, ecotourism or other special types of tourism). Additional analysis of these effects and the related attitudes in rural communities will provide valuable contributions to resident attitudes' literature.

\section{Acknowledgement}

This study was conducted as a part of National Project of Ministry of Education, Science and Technological Development (No. 47024).

\section{References}

Baum, S., 2012. 'The Tourist potential of Rural area in Poland'. Eastern European Countryside 17 (1), pp. 107-137.

Brougham, J., Butler, R., 1981. 'A segmentation analysis of resident attitudes to the social impact of tourism', Annals of Tourism Research 7, pp. 569-590.

Gursoy, D., Chi, C.G. and Dyer, P., 2009. 'An examination of locals' attitudes'. Annals of Tourism Research 36, pp. 723-726.

Gursoy, D., C. Jurowski, and M. Uysal, 2002. 'Resident Attitudes: A Structural Modeling Approach'. Annals of Tourism Research 29, pp. 79-105.

Haralambopoulas, N., Pizam, A., 1996. 'Perceived impacts of tourism: The case of Samos'. Annals of Tourism Research 23, pp. 503-526.

Husbands, W., 1989. 'Social status and perception of tourism in Zambia'. Annals of Tourism Research 16, pp. 237-253.

Kaiser, H.F., 1974. 'An index of factorial simplicity'. Psychometrika 39, pp. 31-36.

Korca, P., 1998. 'Resident Perceptions of Tourism in a Resort Town'. Leisure Sciences 20, pp. 193-212.

Kuvan, Y., Akan, P., 2005. 'Residents' attitudes toward general and forest/related impacts of tourism: the case of Belek, Antalya.' Tourism Management 26(5), pp. 691-706.

Lankford, S. V., Howard, D. R., 1994. 'Developing a Tourism Impact Attitude Scale'. Annals of Tourism Research 21, pp. 121-139.

Liu, J. C., Var, T., 1986. 'Resident attitudes toward tourism impacts in Hawaii'. Annals of Tourism Research 13, pp. 193-214. 
Long, P. T., Perdue, R. R. and Allen, L., 1990. 'Rural resident tourism perceptions and attitudes by community level of tourism. Journal of Travel Research 28(3), pp. 3-9.

Nunnally, J.C., 1978. Psychometric theory, New York: McGraw-Hill.

Pizam, A., 1978. 'Tourism impacts: The social costs to the destination community as perceived by the residents'. Journal of Travel Research 16, pp. 8-12.

Snaith, T., Haley, A., 1999. 'Residents' opinions of tourism development in the historical city of York, England'. Tourism Management 20, pp. 595-603.

Thompson, P., Crompton, J. L. and Kamp, B. D., 1979. 'A Study of the attitudes impacted groups within a host community toward prolonged stay tourist visitors.' Journal of Travel Research 17(3), pp. 2-6.

Tourism Strategy of The Republic of Serbia - the first phase report. Faculty of Economy Belgrade and Horwath Conulting Zagreb, 2005.

Urn, S., Crompton J. L., 1987. 'Measuring Resident's Attachment Levels in a Host Community'. Journal of Travel Research 26(1), pp. 27-29.

Wang, Y., Pfister, R.E. and Morais, D.B., 2006. Residents' attitudes toward tourism development: a case study of Washington, NC. Available from: http://www. nrs.fs.fed.us/pubs/gtr/gtr_nrs-p-14/54-wang-p-14.pdf (Downloaded: 201305-15)

http://www.b92.net/putovanja/zanimljivosti.php?yyyy=2012\&mm $=03 \& d d=$ 05\&nav_id=587962, 2013-05-19.

http://www.vajati.com/srp/?p=116, 2013-05-19.

http://www.paunpress.com/user/tur.php?id=921), 2013-05-19.

http://www.stil-magazin.com/clanak/broj-69-24-april-2008/dragacevo, 201305-19. 